\title{
The Centenary of the League of Nations: Colonial India and the Making of International Law
}

\author{
Amritha V.Shenoy*
}

1

\section{Introduction}

The wave called "turn to history" in international law narrates various historical aspects of international law. This turn introduced a sub-discipline namely, the "History of International Law. However, narrating the history of international law is not a new phenomenon. History has been indispensable to the Third World Approaches to International Law (TWAIL). In the words of R.P. Anand, "the present cannot be properly assessed, nor future projected, without an understanding of the past". The second generation of TWAIL scholars connects history to the present. ${ }^{2}$ Comparing the writings of TWAIL scholars on historical aspects of international law to the present writers on the discipline, one can see that Eurocentric histories are reiterated. The Eurocentric turn to history needs to be challenged by the narration of alternative histories. The alternative histories need to point out the principles of international law that existed in different civilisations so that modern international law can truly become a universal law.

There are rules that governed war, treaty-making, diplomacy, and trade in many civilisations of the world. However, the existence of an international organisation in pre-nineteenth century cannot be found in other civilisations of the world. ${ }^{3}$ International organisations were formed in the nineteenth century. The craving for co-existence and the catastrophes of the World Wars gave an impetus to the formation of international organisations in the twentieth century. ${ }^{4}$ Thus, the consciousness of a State to move

\footnotetext{
* Assistant Professor, Kathmandu School of Law, Bhaktapur, Nepal. I would like to express my gratitude to Sakshi Shree, Doctoral Candidate, Centre for Japanese Studies, Jawaharlal Nehru University for providing valuable suggestions.

1 R.P. Anand, New States and International LaW 5 (2nd ed. 2008).

2 Antony Anghie, Imperialism, Sovereignty and the Making of International LAW 139 (2004).

3 Clive Archer, International Organizations 5 (James Crawford \& John S. Bell eds., 3rd ed. 2001).

4 Inis L. Claude, JR., Swords into Plowshares 17 (4th ed. 1964).
} 
beyond national interests, i.e., internationalism, led to the creation of international organisations. ${ }^{5}$

The pioneer international organisations were for postal services, technology, humanitarian aid and other matters. ${ }^{6}$ The League of Nations was the first international organisation that dealt with pervasive topics affecting human life. It had an inextricable link to the International Labour Organisation, international health organisations, and interntional economic and financial organisations.

Remembering the organisation on its centenary, the League of Nations, despite its demise, was a breakthrough idea not only for international relations but also for challenging various concepts of international law itself. It posed a challenge to the positivist idea that State was the only subject of international law. It gradually widened the ambit of international law. ${ }^{7}$ The formation of an international organisation was clearly piercing through the sovereignty of the States. Many internal matters were discussed directly or indirectly in the League. Therefore, in theoretical terms, international law was moving from positivism to liberalism.

However, only European states became members of the international organisations established before the League. For instance, the Central Commission for the Navigation of the Rhine was formed as a result of the Congress of Vienna in 1815. It was a creation of Europe with European members. Eurocentrism was challenged by the formation of alternative organisations. The Soviet Union and the colonised nations together formed the Comintern or Communist International in 1919, challenging imperialism.

Apart from Eurocentrism, patriarchy was challenged also by the formation of women's organisations. There were three prominent international women's organisations in the post-First World War era, viz., the International Alliance of Women, the International Council of Women, and the Women's International League for Peace and Freedom. The Women's International League for Peace and Freedom organised a meeting of women during the First World War when most of the other inter-governmental organisations were not functional.

5 Akira Iriye, Global Community: The Role of International Organizations in the Making of the Contemporary World 9-10 (2002).

6 Commerce was the triggering point for the proliferation of international organisations. Health was another concern. The international organisations included the International Telegraphic Bureau (1868), the General Postal Union (1874), the International Bureau of Weights and Measures (1875), the International Union for the Publication of Customs Tariffs (189o), the Metric Union, and International Health offices in Vienna, Paris, and Havana.

7 This challenge was manifest after the creation of the United Nations. However, the League of Nations was one of the first steps. 
Colonial India was a member of some of the international organisations. In 1874, a representative for India signed the Berne Convention, by virtue of which India became a member of the Universal Postal Union in 1876. In 189o, India ${ }^{8}$ was represented by a delegate at the Conference of the International Union for the Publication of Customs Tariffs. British India signed the International Wireless Telegraph Convention in 1912. India had a separate vote at the International Radiotelegraph Conference in 1912. Colonial India was party to 150 multilateral treaties ${ }^{9}$ and 44 bilateral treaties. ${ }^{10}$ Certain international agreements were also signed separately by colonial India. ${ }^{11}$ With regard to the alternative organisations, M.N. Roy, an Indian, was a member of the executive committee of the Comintern. Colonial India acceded to the International Alliance of Women to promote universal suffrage. ${ }^{12}$

Colonial India was a founding member of the League of Nations. 2019 was the centennial year of the formation of the League of Nations. Its contributions as one of the first international organisations are remarkable in the history of international law. Nevertheless, in the narrations of the League's history, a substantial part is neglected; it is the contribution of the colonies. Their contributions remain a part of alternative histories. The struggles of the people of colonial India, internal as well as external struggles, remain neglected. The period when colonial India was a member of the League reflects the way the Empire operated. ${ }^{13}$ Therefore, the present article is an attempt to narrate an alternative history to highlight the contributions as well as struggles of colonial India in the international arena.

The article describes the political entity called colonial India by examining its position in international organisations despite being a colony. It discusses the ground for Indian membership in the League. Membership in an international organisation gives rise to financial responsibilities to contribute to the sustenance of the organisation. Hence, the article elucidates financial contribution and disproportionate representation with regard to colonial India. It highlights the problems faced by the Indian delegation due to the dominance of Europe in the League. It points out the issues discussed in the League on India. The history narrated herein also looks at the positive

\footnotetext{
8 India hereafter means colonial India.

$9 \quad$ See generally 124 L.N.T.S., 26 U.N.T.S.

$10 \quad$ See generally 32 L.N.T.S., 12 U.N.T.S.

11 Oliver J. Lissitzyn, Territorial Entities other than Independent States in the Law of Treaties, 125 Recueil Des Cours 1, 72 (1968).

12 IRIYe, supra note 5, at 29-30.

13 B.S. Chimni, India, in The OXford Handbook of International LaW in Asia ANd THE PACIFIC 551 (Simon Chesterman, Hisashi Owada \& Ben Saul eds., 1st ed. 2019).
} 
aspects of colonial Indian membership in the League. The article views history not only against Eurocentrism but also the role the different forms of hierarchy, i.e., of class, caste, and gender, played in the participation of India in international fora.

Colonial India was a complicated political entity. As mentioned in the Paris Peace Conferences, India was of a composite character. ${ }^{14}$ Colonial India had broadly two components, viz. the territories governed by the British administration and the 562 Princely States..$^{15}$ The Governor-General dealt with the relationship between these two components. The Princely States had autonomy over internal matters whereas external affairs were controlled by the British. The Princely States did not have the power to enter into foreign relations with the external powers. The Princely States of India were like vassal states under the control of Britain. ${ }^{16}$

With regard to the territories governed by the British Administration, the British had control over internal as well as external affairs. ${ }^{17}$ The right to declare war lay with the British Crown. Diplomatic relations were maintained on behalf of colonial India by the India office in London. The Government of India was comprised of a Foreign Department. The department did not deal with matters of external relations with other States or international organisations (such as the League of Nations). Thus, the Government of India was confined to territorial disputes and internal matters. ${ }^{18}$

Due to the power exercised by the British, India was not a self-governing territory, neither internally nor externally. ${ }^{19}$ However, India's international personality was maintained as separate from that of Britain because the Interpretation Act of 1889 did not mention India as a colony. Primarily based

\footnotetext{
14 R.P. Anand, The Formation of International Organizations and India: A Historical Study, 23 LEIDEN JOURNAL OF INTERNATIONAL LAW 5, 9 (2010).

15 India meant British India according to Section 18(5) of the Interpretation Act, 1889. Section 18(5) of the Interpretation Act of 1889 defines India as follows:

"British India, together with any territories of any native prince or chief under the suzerainty of His Majesty".

16 Anand, supra note 14, at 11.

17 Id.

18 D.N. Verma, India and the League of Nations 83 (1968).

19 Lissitzyn, supra note 11, at 66.
} 
on the Act, India was accommodated by the British as a member of international organisations. ${ }^{20}$

There were two reasons for granting membership to India in international organisations, specifically the League of Nations. The primary reason was that the British had a vested interest to increase Britain's "voting strength" in international fora. ${ }^{21}$ Therefore, Britain included other Dominions also as members. Thus, the total vote on behalf of the British counted to six (Great Britain, India, Australia, New Zealand, Canada, and South Africa). Six votes were good enough to increase the strength of the British Empire. ${ }^{22}$

Prominent personalities like Govind Ballabh Pant, Bhagwan Das, and others criticised India's membership in the League as beneficial to the British. The British denied this allegation by pointing out Article 5 of the Covenant which mentions the voting procedure of the League and demands unanimous votes, with few exceptions, in the Assembly and the Council. ${ }^{23}$ The British reply was not satisfactory in the appointment of committees and the matters of procedure. The British wielded much power by the voting strength it had in the Assembly. It also had an impact on the membership in the Council. ${ }^{24}$

Another reason for including colonial India in the League was that it was a major political entity which lent a helping hand to the British and its allies during the First World War. The admission of members to the League was the discretion of the States that met at the Paris Peace Conference. It is pertinent to note that while India was given membership in the League, India's participation in the First World War itself was a result of British rule in India. ${ }^{25}$

20 R. Kemal, The Evolution of British Sovereignty in India, in 8 Harbans S. Bhatia, Political, Legal and Military History of India 119, 122 (1986).

21 Till 1919, India was represented by the officials appointed by the British. Anand, supra note 14 , at $7-8$.

V. Shiva Ram \& Brij Mohan sharma, India and the League of Nations 142 (1932).

23 Article 5 of the Covenant of the League of Nations states:

Except where otherwise expressly provided in this Covenant or by the terms of the present Treaty, decisions at any meeting of the Assembly or of the Council shall require the agreement of all the Members of the League represented at the meeting.

All matters of procedure at meetings of the Assembly or of the Council, including the appointment of Committees to investigate particular matters, shall be regulated by the Assembly or by the Council and may be decided by a majority of the Members of the League represented at the meeting.

The first meeting of the Assembly and the first meeting of the Council shall be summoned by the President of the United States of America.

24 VERMA, supra note 18, at 24-25.

25 Id. at 29. 
Due to the composite character of India, one Prince from the Princely States was part of the Indian delegation to the League Assembly's Annual Sessions. The Princely States supported the British during the First World War. Furthermore, their inclusion in the delegation meant that they would convey international obligations to the Chamber of Princes, and the Government of India did not have to persuade them separately. An Indian Prince was appointed as a cultural diplomat in the League. Hence, the cooperation of the Princely States and the British was manifest with the signature of the Maharaja of Bikaner in the Treaty of Versailles. This step brought both political entities (British India and the Princely States) closer. ${ }^{26}$

Be that as it may, membership in the League did not grant any autonomy to the Indians. The representatives of colonial India to international fora were selected by the British. ${ }^{27}$ The question of authority in selecting Indian delegates to international organisations was a tough one. The issue revolved around the superiority of the Secretary of State or the Government of India. The appointments were to be made, as decided in 1920, in "prior consultation and agreement" between the Government of India and the Secretary of State. ${ }^{28}$ The India Office despatched the appointment letter. The name of the authority was not mentioned so that an impression that superiority of the Secretary of State existed. The instructions were issued by the India Office on the information given by the Government of India. When necessary, they were given by the Secretary of State in consultation with the Government of India.

After the conference, delegates submitted reports to the Secretary of State, and a copy was despatched to the Government of India. This decision was made in 1920. Thus, control was attempted to be imposed on India's representation in international fora during the colonial era. The treaties signed by India were ratified by "an instrument of ratification signed by the King on the advice of the British Cabinet". ${ }^{29}$ In matters of less gravity, the Secretary of State for India did the ratification.

Sometimes, the arguments formulated by the British were reformulated according to the opinion of Indians. ${ }^{30}$ The freedom of expression for India was not untrammelled. It was under British control. However, it is laudable that whatever autonomy the Indian delegates obtained, they utilised it for the benefit of India and her interests. Emulating the Latin American countries that

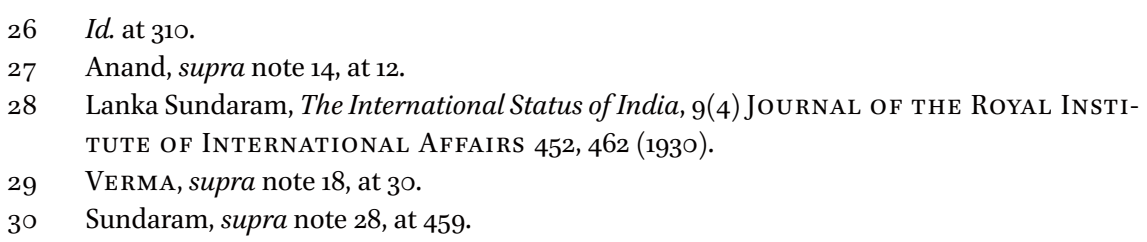


took a joint stand in many instances, the British made joint decisions for the Empire as a whole. ${ }^{31}$ Nevertheless, the important political matters "affecting the Empire as a whole" were left to the British Government. ${ }^{32}$

With regard to the Princely States, the Prince could not express on behalf of his fraternity and he was sent as a part of British India. ${ }^{33}$ Whenever the Government of India accepted some international obligations, it had to appease the Indian Princely States to follow similar obligations. Since problems would arise with negotiations, the Covenant of the League of Nations and other conferences had provisions to exclude territories from its purview. ${ }^{34}$ When the British realised that some obligations can never be expected to be followed by the Princely States, they excluded those territories.

Complications arose in the case of Princely States because they had seceded their external autonomy but did not give up internal autonomy. There were instances when the Princes signed the conventions and later, after the discussions in the Chamber of Princes, they refused to fulfil international obligations. They claimed autonomy in internal administration. The Government of India issued a circular on January 21, 1926, asking the Princely States to follow international obligations under the League of Nations as deem fit in their internal administration. ${ }^{35}$ The Princely States maintained the position that the Government of India should not interfere in their administration. The assertion of the Princely States led the Government of India to exclude them from the application of many important treaties like the Hague International Opium Convention, the Slavery Convention, and the International Convention for the Suppression of the Traffic in Women and Children, etc.

Gradually, some autonomy was granted to India. J. C. Coyajee explains the situation as India being granted "quasi-independence in her external relations". ${ }^{36}$ One of the reasons for autonomy is because of the freedom struggle against the colonial rule in India. As far as international obligations were concerned, the matters concerning bilateral relations with a foreign power were dealt with by the British government. In the matters that affected India only, discretion was given to India. Treaties like the Locarno treaty had provisions that the issues affecting India and other Dominions were to be decided on their consent. The Imperial Conferences of 1923 and 1926 made it obligatory on the Empire to let the dominions and India decide whether to sign treaties or not.

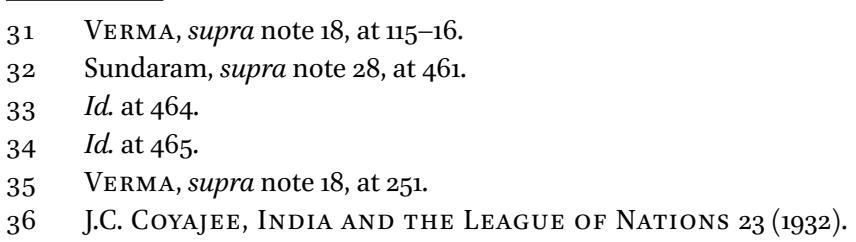


The inclusion of Indian Princes projected India as one political unit, ${ }^{37}$ and the Indian nationalists utilised this to propose a federal structure of independent India. ${ }^{38}$ Later, the Government of India Act of 1935 altered the relations between the Government of India and the Princely States. The Rulers of the Princely States had to sign an instrument of accession. They could specify in the instruments as to the matters on which the Government of India could enter into international treaties on behalf of the Princely States. They were also empowered to opt out of international labour conventions. The Princely States were termed as "international orphans" because they did not have obligations under many international treaties due to such reservations. ${ }^{39}$

From the above account of the political structure of colonial India and its subsequent participation in international organisations, many scholars termed the situation as anomalous in nature. D. H. Miller termed India's membership in the League as "an anomaly among anomalies". ${ }^{40}$ V. Shiva Ram and Brij Mohan Sharma opined that "India is a political curiosity inside the League". ${ }^{41}$ India's situation in the period between 1919 and 1947 is described as an "anomalous situation" again by T.T. Poulose. ${ }^{42}$ The Princely States were in a more complicated position. The Covenant of the League of Nations did not have a provision for the representation of different political entities. Despite such absence of provision, the Indian Princes represented the Princely States in the League. Therefore, such representation was termed as an anomaly by D.N. Verma. ${ }^{43}$ Thus, the political entity called colonial India had an anomalous position in international organisations.

Two Imperial Conferences, or Colonial Conferences, were convened in 1887 and 1897. India did not participate in both conferences. In 1902, the Third Colonial Conference was held wherein preferential tariff in the jurisdiction of the Empire was discussed. The representation of India was inevitable, and therefore, an invitation was sent to the Government of India. A representative

\footnotetext{
37 RAM \& SHARMA, supra note 22, at 143.

38 VERMA, supra note 18 , at 246.

39 Int'l Labour Org., Record of Proceedings for its Twenty-Sixth Session, at 228 (1944).

40 As quoted in VERMA, supra note 18, at 20. See CoyajEe, supra note 36, at 26.

41 RAM \& SHARMA, supra note 22, at 139.

42 T.T. Poulose, India as an Anomalous International Person (1919-1947), 44 BRITISH YEARBOOK OF INTERNATIONAL LAW 201, 206 (1970).

43 Verma, supra note 18 , at 244.
} 
of the India Office attended the conference. It was an "ad-hoc representation at the imperial conference". ${ }^{4}$ In the Fourth Colonial Conference conducted in 1907, the representative of the Secretary of State for India attended. The Fifth Colonial Conference was held in 1911. Lord Crewe, the Secretary of State for India, participated in one of its meetings and discussed the issue of Indian immigrants to the Dominion. Issues related to India were discussed in the conferences through the participation of the India Office.

India's demand for participation in the Imperial Conferences was given impetus by the support provided by India to Britain in the First World War. ${ }^{45}$ The support changed the attitude of the British public and the Dominions towards India. On 22 September 1915, Mian Muhammad Shafi put forth a resolution in the Legislative Council demanding an invitation to India for participation in the Imperial Conferences in the future. The Governor-General of India, Lord Hardinge, assured consideration. The War Cabinet decided in January 1917 to include India in the forthcoming conference. ${ }^{46}$ In March 1917, the War Cabinet began its meetings. India was represented by James Meston, S.P. Sinha, and the Maharaja of Bikaner. A permanent participation of India in the conferences was decided. A resolution was passed for the Dominions and India conferring "a right to an adequate voice in foreign policy and foreign relations". ${ }^{47}$ India was not mentioned in the original text, but S.P. Sinha insisted on an amendment to include India. India's claim on enemies of the First World War amounted to 8o,ooo,oo Rupees. This claim made the representation of India inevitable in the Paris Peace Conference. India was represented at the Paris Peace Conference by E.S. Montagu, the Secretary of State for India, the Maharaja of Bikaner, and S.P. Sinha, the Parliamentary Under-Secretary of State for India.

India participated in the Paris Peace Conference, 1919. In 1919, India signed the Treaty of Versailles and other accompanying peace treaties. India's membership in the League was dependent on the signing of the Treaty of Versailles. Thereby, India became an original member of the League of Nations. ${ }^{48}$

\section{$44 \quad I d$. at 2 .}

45 Id. at 3 .

46 The Imperial War Conference of 1917 "passed a resolution which defined the selfgoverning Dominions 'as autonomous nations of an Imperial Commonwealth', and India 'as an important portion of the same', and claimed for the Dominions and India an adequate voice in the regulation of the foreign policy and foreign relations of the Empire". See Sundaram, supra note 28 , at 454 .

47 VERMA, supra note 18 , at 6.

48 India was a participant in the Paris Conference wherein the Covenant of the League was drafted. It was listed as one of the original members. Original members were included 
As a prelude to membership in the League, India struggled to be a participant in the Imperial Conferences. The struggle for membership in the League continued due to the opposition from the French and others, whereas the USA supported and debated in its Senate on India's membership in the UN. President Woodrow Wilson was the mastermind behind the creation of the League as highlighted in his Fourteen Points Agenda Speech. The US supported decolonisation for the creation of markets in the new states thus formed. In this context, the US supported "colonies enjoying full powers of self-government". ${ }^{49}$ However, the US Senate did not approve the League Covenant. In the context of Indian membership in the League, British hypocrisy was debated in the US Senate. Senator Norris pointed out the atrocities committed by the British in the Jallianwala Bagh Massacre. ${ }^{50}$ Despite such inhuman acts, the British showed the participants of the Paris Conference that India was governed democratically. However, by virtue of Article 1 of the League Covenant, India became a member of the League. ${ }^{51}$

\section{Eurocentrism in the League}

Due to prominent European representation in the League, European interests were discussed vastly. It was known as a "European organisation". ${ }^{2}$ Due to European dominance, D.N. Verma opines that "oriental conditions and interests were in this way accorded a condescending and somewhat contemptuous tolerance, and then forgotten, while attention was concentrated on Western problems". 53

Indians opposed Eurocentrism in the League. The League of Nations aimed at maintaining the status quo. The status quo was not acceptable to the

according to Article I, paragraph I of the Covenant that states, "the original members of the League shall be those of Signatories which are named in the Annex to the Covenant". VERMA, supra note 18 , at 15 .

50 The negotiations at Versailles were conducted as an epilogue to Jallianwala Bagh Massacre and the Satyagraha of Mahatma Gandhi. See ANG HIE, supra note 2, at 139.

Article 1 of the The Covenant of the League of Nations provides:

"Any fully self-governing State, Dominion or Colony not named in the Annex may become a member of the League if its admission is agreed to by two-thirds of the Assembly, provided that it shall give effective guarantees of its sincere attention to observe its international obligations".

52 Ram \& Sharma, supra note 22, at 93; Stephen Legg, An International Anomaly? Sovereignty, the League of Nations and India's Princely Geographies, 43 Journal of Historical GEOGRAPHY 96, 98 (2014).

53 VERMA, supra note 18 , at 84 . 
Indians who were struggling for freedom..$^{54}$ For them, the League was a manifestation of imperialism. They wanted to get rid of the clutches of imperialism and colonialism.

The Council of the League of Nations was an arena of the great powers. It did not have representation from Africa, Australia, North America, and South America. Ram and Sharma ${ }^{55}$ staunchly criticise the composition of the League Council by stating that "Although the chief aim of the League is to inspire confidence in all the nations of the world and to treat them as equals, still in the composition of its organisations there is clearly inequality prevailing". They opined that India and China deserved to be permanent members of the Council due to their large population. ${ }^{56}$ India's seat in the Council was further bleak due to the British rule.

In the League Secretariat, there were very few employees from India (about half a dozen). ${ }^{57} \mathrm{~A}$ representation was sent to the League of Nations in 1926 on the appointment of Indians in the League of Nations. One of the earliest appointments of Indians made to the League of Nations Secretariat was that of P.P. Pillai. The representation in the Secretariat was again disproportionate to the heavy financial contribution given by colonial India. ${ }^{58}$

The election of an Indian as the Judge of the Permanent Court of International Justice (PCIJ) was also a difficult task. Candidates like Amir Ali and Sultan Ahmad contested for elections of the judicature in vain. Even though the Court intended to represent all the principal legal systems and civilisations of the world, it was not fulfilled due to European dominance.

The British accepted the optional clause ${ }^{59}$ of the Statute of the PCIJ in 1929 after a long contemplation. The exceptions given by India to the optional

\footnotetext{
$54 \quad$ Id. at 273 .

55 RAM \& SHARMA, supra note 22, at 193.

56 Id. at 166; Ram and Sharma proposed "reshuffling" of the council. In their words, "Some of the seats on the Council should be assigned on a territorial basis. For example, Europe and Asia should each get three seats, America two, Africa two and Australia one. After that, some seats should be distributed on population basis, and India and China, being the countries with the largest populations in the world, should each get a permanent seat. Seats may be assigned on the basis of the principal forms of civilisation, such as Anglo-Saxon, Teutonic, Slev, Latin, Chinese, Japanese, Hindu and Mohammedan etc. There should be a number of non-permanent seats open to election as at present". Id. at 208.

$57 \quad$ Id. at 167.

58 League of Nations Notes, 5(7) Bulletin of International News 17, 21 (1928).

59 The Indian delegation led by Mr Habibullah signed the optional clause on 19 September 1929. He made the following statement (United States Department of State, Treaty Information: Permanent Court of International Justice - India, 2 The Department of State Bulletin 451, $45^{2}$ (1940)).
} 
clause in effect nullified compliance with it. ${ }^{60}$ Due to such exceptions, India could not settle disputes (for instance, with the problem of Indian emigrants in South Africa) with the other imperial dominions and left them to the Privy Council.

The Eurocentric nature of the League was reflected in the Mandate System which kept all members of the League under the control of the great powers. The Mandate System was formulated to promote self-government among the colonies and to make them a part of the "international system as sovereign, independent nation-States". 61 It changed the language "civilised and uncivilised" to that of "backward and advanced". ${ }^{62}$ This reflects the Eurocentric idea of waiting for the "backward" nations to become "advanced" with the help of the "civilised" nations. ${ }^{63}$

Indian public opinion was against the Mandate System because of the delay in granting self-determination by the establishment of the System in the League. The discontent amongst Indians was also due to the issue of Tanganyika. It was a mandate territory under the British. Indians residing in the area faced discrimination because of British policies. The mobilisation of Indian public opinion against it led the Government of India to take the issue before the Permanent Mandates Commission. India could not move the PCIJ

"On behalf of the Government of India and subject to ratification, I accept as compulsory ipso facto and without special Convention, on condition of reciprocity, the jurisdiction of the Court in conformity with Article 36 , para 2, of the Statute of the Court, for a period of 10 years and thereafter until such time as notice may be given to terminate the acceptance, over all disputes arising after the ratification of the present declaration with regard to situation or facts subsequent to the said ratification, other than - disputes in regard to which the parties to dispute have agreed or shall agree to have recourse to some other methods of peaceful settlement; and disputes with the Government of any other Member of the League which is a Member of the British Commonwealth of Nations, all of which disputes shall be settled in such a manner as the parties have agreed or shall agree; and disputes with regard to questions which by international law fall exclusively within the jurisdiction of India. And subject to the condition that the Government of India reserve the right to require that proceedings in the Court shall be suspended in respect of any dispute which has been submitted to and is under consideration by the Council of the League of Nations, provided that notice to suspend is given within 10 days of the notification of the initiation of the proceedings in the Court and provided also that such suspension shall be limited to a period of 12 months or such longer period as may be agreed to by the parties to the dispute or determined by decision of all the Members of the Council other than the parties to the dispute".

6o VERMA, supra note 18 , at 95 .

61 ANG HiE, supra note 2, at 116.

62 ANghiE, supra note 2, at 189.

63 Dipesh Chakrabarty, Provincializing Europe: Postcolonial Thought and Historical Difference (Reissue ed., 2008). 
because of the exceptions made in the optional clause. ${ }^{64}$ All these issues arose due to the Eurocentric nature of the League. It ended up as politics of the great powers. This affected the Indian delegates to the League directly.

\section{5}

\section{Problems Faced by the Indian Delegation}

The Indian delegation, as previously mentioned, was comprised of the British, Indian Princes, and Indians. The British, who were part of the Indian delegation to the League, largely made decisions on behalf of India. At times, the British expressed Indian interests. For instance, William Meyer strongly supported the reduction of India's expenses in the League of Nations. However, when the interests of Britain and India clashed, the British served the former.

The Indian delegates faced many problems. Due to the lack of instructions and delays in instructions from the India Office, the Indian delegates had to face difficulties in the conferences they represented. ${ }^{65}$ Moreover, the delegates sent on behalf of India were less in number in comparison to any other member of the League. The Indian delegates maintained professional contact, unlike other members with more delegates who entered into unofficial diplomacy. The constant demand of the delegates added three substitute delegates to represent India in the Seventh Assembly of the League of Nations.

India did not have a permanent representative in Geneva. Many nations had permanent representatives, but the Government of India was reluctant to incur expenditure. The absence of a permanent representative in Geneva led to a setback to Indian interests in many issues. ${ }^{66}$ The members of the Indian legislature demanded the appointment of an Indian head in the delegations sent on behalf of India. The British rejected it in the pretext that an Indian could not "appreciate the guiding principles of His majesty's Government".67 Indian legislators demanded an Indian head to get rid of the allegation against Indians that they are reiterating the British views in international fora. The British possessed the feeling of racial superiority. It never justified their conscience that the head of the delegation could be an Indian leader. ${ }^{68}$ Due to the untiring efforts of the Indian legislators like P. C. Sethna, the demand was met by the British when Mohammad Habibullah was appointed as the head

\footnotetext{
64 VERMA, supra note 18 , at 98.

65 Id. at 52.

$66 \quad I d$. at 56.

$67 \quad I d$. at 68 .

68 Id. at 70.
} 
of the Indian delegation to the Tenth Assembly of the League of Nations. The uniqueness of the report submitted by this delegation was that it made some recommendations to elevate the position of India in the League. One of the recommendations was on India's candidature in the Council elections. The recommendations were not materialised due to the disagreement of the government. After that, an Indian headed the delegation.

Another problem faced by the delegates was inexperience because, every time, new representatives were appointed for representation. They were never part of committees of the League due to their lack of experience. Demand was raised for continuity in the appointments, which was met in 1930. With the help of such reappointments, Aga Khan was elected as Vice-President of the Assembly, Denys Bray became a part of many sub-committees, and H. Mehta was appointed as General Rapporteur of the Fourth Committee. The Indian legislators, through debates and negotiations with the British, struggled to solve the abovementioned issues through debates and constant demands to the British. However, the representation was British dominated, and even if it included a few Indians, it avoided women and Dalits. In present times, the representation of women and Dalits remains less.

Issues Discussed in the League on India

The League of Nations analysed a plethora of problems. Some discussions concerned India and her interests. For example, a special report submitted in the Assembly was on the claim of India to be represented in the Governing Body of the International Labour Office. The representation in the Governing Body was emphasised in one of the sessions of the Assembly in JulyAugust 1920.

Another issue that touched upon colonial India was that of disarmament. The representatives of India in the League did not support disarmament because of the general notion that it would mean putting India's security at stake. The British opinion was that the tribes of Afghanistan were dangerous in the frontiers and were waiting to attack without following any principles of international humanitarian law. The British exaggerated the power of these tribes, and the actual threat was assessed from Russia. ${ }^{69}$ Moreover, under British rule, Indian opinion in the League reflected that of the British.

$69 \quad I d$. at 103. 
The British could not pull out the army deployed in India also because of the ongoing freedom struggle against them. ${ }^{70}$

The clamour caused by the issue of opium trade caught the attention of the League. Opium became a menace in many parts of the world. Opium wars were fought between India and China. An action against opium trade became imperative. In this regard, the US government organised two conferences on opium traffic in Shanghai (1909) and Hague (1912). India ratified the Hague Convention in 1920 but did not comply with it. Indian opium was sold even after the ratification.

Indian delegates to the League in 1921 and 1922 cited the medical and scientific use of opium in India and hence, could not support the ban of opium totally. The Geneva Conferences, under the aegis of the League, in 1924 and 1925 also dealt with opium issue. The US and China opposed the Government of India's policy as the sale of opium was rampant in these States. They blamed India for the production of opium. India opined that an agreement should be reached between the opium-producing countries.

Opium was vastly used in India. The use of opium in India was severely criticised by medical experts. The use of opium in India was to such an extent that women who worked in industries drugged their babies with opium to prevent them from crying. The Government of India's policies on opium were criticised as inadequate. Since the Government earned a lot of revenue from opium trade (national as well as international), it did not want to restrict its use. ${ }^{71}$ It appointed the Royal Commission on Opium. The Commission submitted a report in 1895. It was known to be a farce because it stated that Indians used opium for medicinal purposes and that the Government's policy was based on it. ${ }^{72}$

The Government of India's opium policy was criticised by Mahatma Gandhi and the Indian National Congress. Due to pressures from international and national spheres, the consumption of opium in India was reduced drastically despite the fact that it was a blow to India's revenue. ${ }^{73}$ In March 1926, a resolution was passed by the Indian legislature to stop the export of opium for any other purpose except medicinal and scientific reasons. The Government of India tried to control domestic consumption with the enactment of the Opium Act.

\footnotetext{
$70 \quad I d$. at 105.

71 RAM \& SHARMA, supra note 22, at 15 O.

72 VERMA, supra note 18 , at 216.

73 RAM \& SHARMA, supra note 22, at 153.
} 
Further conventions on opium and other narcotic drugs entered in the League era were "the Geneva Convention of 1925, the Geneva Agreement on Opium Smoking of 1925, the Drugs Limitation Convention of 1931, the Bangkok Agreement on Opium Smoking of 1931, and the Convention for the Suppression of the Illicit Traffic in Dangerous Drugs of $19366^{\prime 74}$ India also participated in these conventions.

These conventions were a result of deliberations in the League on the use of other narcotic drugs. Smuggling of narcotic drugs like cocaine in India led the Indian delegates to request the League in 1926 to check the widespread problem of narcotic drugs. Due to the pressing need for a solution, a conference (the Conference on Limitation on the Manufacture of Narcotic Drugs) was convened under the League through a resolution passed in 1930 by the Assembly. The outcome of the conference was a convention in 1931 based on the Geneva International Opium Convention of 1925. India signed the Convention. The Convention was an unprecedented step towards the regulation of an industry under "international co-operation" and "that manufacture in its economic aspect has been wholly subordinated to higher humanitarian and moral aims". ${ }^{75}$

The League also discussed issues concerning women and children. One of the important conventions on women and children signed by India under the aegis of the League is the Convention for the Suppression of the Traffic in Women and Children of 1922. The Indian Penal Code declared trafficking as an offence and prescribed punishment for the same. The laws were inadequate, and the penal code was amended to provide more protection to women below 18 years of age. The provincial governments also passed legislations to curb trafficking like the Madras Suppression of Immoral Traffic Act of 1930. These steps were taken to bring national laws in consonance with international laws.

Child health, infant mortality, and child welfare caught the attention of the League. The Government of India cited that the conditions in India were not amicable to introduce legislations for child welfare. In 1928, a report was submitted to the Fifth Committee stating that the age of marriage was gradually rising and that child marriages were decreasing in number. ${ }^{76}$ Some legislations on children were passed like the Madras Juvenile Offenders Act (amended 1930). Laws were passed in provinces raising the age of marriage. The International Convention for the Suppression of the Circulation of and

\footnotetext{
74 Anique H.M. Van Ginneken, Historical Dictionary of the League of NATIONS 142 (2006).

75 RAM \& ShARMA, supra note 22, at 121.

76 VERMA, supra note 18 , at 187.
} 
Traffic in Obscene Publications was signed in 1923. In India, obscene literature and advertisements were prevalent at that time. India ratified this convention in 1924. To implement this international convention, India made amendments to the Indian Penal Code and the Criminal Procedure Code.

In one of the sessions of the Assembly in 1922, the issue of slavery was discussed. After that, the Secretariat formed a Temporary Committee on Slavery. The Slavery Convention was signed under the auspices of the League in 1926. India was ready to sign the treaty provided that she could make some reservations with the exclusion of territories practising some forms of slavery and those on which the Government of India did not have direct control. Another motive behind such a reservation was that the Government wanted to maintain good relations with the Princely States. In pursuance of signing the treaty, the Government released all slaves from the Hukawng Valley in Burma.

With regard to the issue of statelessness, a Special Protocol Concerning Statelessness was formulated under the aegis of the League. On 28 September 1932, India signed the Special Protocol as a separate member of the League of Nations. Article 1 of the Protocol provided the following international obligation on the signatories:

If a person, after entering a foreign country, loses his nationality without acquiring another nationality, the State whose nationality he last possessed is bound to admit him, at the request of the State in whose territory he is:

(i) If he is permanently indigent either as a result of an incurable disease or for any other reason; or

(ii) If he has been sentenced, in the State where he is, to not less than one month's imprisonment and has either served his sentence or obtained total or partial remission thereof.

In the first case, the State whose nationality such person last possessed may refuse to receive him if it undertakes to meet the cost of relief in the country where he is as from the thirtieth day from the date on which the request was made. In the second case, the cost of sending him back shall be borne by the country making the request.

From the above highlights of issues on disarmament, opium, slavery, or others, the British Empire's interests were predominant while talking on behalf of India. However, the opinions of the Indians helped change some of the aspects like restrictions on the opium trade and using the positive aspects of international law for the benefit of the Indians. This was a result of constant struggle against the British rule in colonial India. 
India's membership in the League had both positive and negative aspects. The negative aspects of European dominance, the manifestation of Empire in the League in the name of India, have already been elucidated in the previous sections of this article. However, in the words of scholars, the League was a significant step. In this regard, quoting Stephen Legg, "The League can be considered an apparatus, through the way in which it attempted to reterritorialise the imperial world into an international order, but this also involved deterritorialising and de-scaling imperial sovereignty". ${ }^{77}$ In the words of J.G. Starke, ${ }^{78}$ the League of Nations was a significant step in the evolution of international law.

The League of Nations Covenant, that is to say, Part I of the Treaty of Versailles, 1919, reflected a new theory of the scope and purpose of the international organisation. This was the conception of an international institution, with universal or almost universal membership of the states of the world and devoted to the fulfilment of most general aims in the interests of the international community, namely the promotion of international cooperation, the preservation of international peace and security, the fostering of open, just, and honourable relations between nations, the firm establishment of International Law as the actual rules of conduct between States, and the maintenance of justice and a scrupulous respect for all treaty obligations.

The greatest flaw of the League was that it could not prevent the Second World War. Despite the drawbacks, the League was not a failure as it laid foundations for the United Nations. Kewal Singh states the importance of the League in institutionalising international relations, "By its commitment to the principles of justice to all peoples and nationalities and their right to live on equal terms of liberty and safety with one another whether they be strong or weak, the League marked the first effort to democratize the international relations".79

77 Stephen Legg, Of Scales, Networks and Assemblages: The League of Nations Apparatus and the Scalar Sovereignty of the Government of India, 34 TRANSACTIONS OF THE INSTITUTE OF BRITISH GEOGRAPHERS 234, 243 (2009).

78 J.G. Starke, The Contribution of the League of Nations to the Evolution of International Law, INDiAN YEARBooK OF INTERNATional AfFairs 207, 209 (1964).

79 Kewal Singh, UN's Efforts at Pacific Settlement of International Disputes, in United NATIONS AND INDiA $5^{2}$ (S.C. Parasher ed., 1985). 
With regard to India, some positive aspects of membership in the League cannot be avoided. The first aspect was that India could better develop an international personality and could be recognised as a political entity in the world. It helped her "for the creation of a special international status".80 Indian diplomacy got in shape after membership in the League. ${ }^{81}$ The representatives to the League and inter-related organisations imbued diplomatic skills like negotiations that was carried forward by next generation of diplomats. Indian Political Department members were sent as British Ministers to Afghanistan and Nepal. Consular Officers from India were despatched to many parts of the world like Kashgar, Persia, Muscat, Jeddah, etc. In 1927, India was empowered to enter into commercial treaties directly without the backing of the British government.

"The debate over Indian rights at the League was but one indication of how newly defined international political space in the 1920s threatened domestic governments' ability to control their domestic political governance and discourse". ${ }^{82}$ The membership also appeased the national leaders who were demanding independence in an unprecedented manner. ${ }^{83}$ They understood that the British wanted to show the outside world that Britain was supporting India. The membership gave an impetus for the "constitutional development" of India. ${ }^{84}$ Montagu, by providing the rationale that India was a member of the League, put forth the Government of India Bill before the House of Commons. The British also tried to disprove the allegations that strengthening her voting power was the motive behind including India in the League. Therefore, granting some autonomy to India to govern herself was imperative. ${ }^{85}$ The Government of India Act of 1919 kept out of the Indian legislature's purview to discuss matters on the League. ${ }^{86}$ The first resolution on an international treaty was put forward by Sir Atul Chatterjee in the Legislative Council and by Thomas Holland in the Legislative Assembly to frame laws in consonance with the Washington Conference, 1919, which fixed the hours of work. Thus,

\footnotetext{
8 o Sundaram, supra note 28 , at $45^{2}$.

81 VERMA, supra note 18 , at 35 .

82 Daniel Gorman, The Emergence of International Society in the $1920 \mathrm{~S}$ 140 (2012).

83 VERMA, supra note 18 , at 25.

84 Id. at $35^{-3} 3$.

85 Id. at 41 .

86 Article 8(i) of the rules under the 1919 Act states that "no question shall be asked regarding any matter affecting the relations of His Majesty's Government or the Governor-General in Council with any foreign power".
} 
the Indian legislature attained the status of "competent authority" to decide on such matters. ${ }^{87}$

One of the advantages of membership of the League was that the Indian legislature moved beyond national issues and discussed international issues. ${ }^{88}$ Some of the inter-imperial problems were raised in the League of Nations by India. For instance, the issue of Indians residing in the mandated territories was raised by Maharaja of Nawanagar. Srinivas Sastri criticised the treatment of Indians in the mandated territories in strong words before the League Assembly. ${ }^{89}$ These issues were discussed in international fora by the Indian delegates until a decision was made to restrict such speeches in the Imperial Conference of 1923. In the 1930s, there was a debate in the League of Nations to decide a scale wherein national and international matters would be demarcated. This issue came up during the discussions on trafficking in women and children. The British said that the League could deal only with international matters whereas the League denied such bifurcation. ${ }^{90}$ The Government of India was more "contemptuous" of the League of Nations and did not want to share intricacies of the Empire. ${ }^{91}$

Membership in the League led to India's presence in the non-League conferences like the Washington Conference on Naval Armaments of 1921, the Genoa Economic Conference of 1922, etc. India's membership in the League of Nations made her a part of the Permanent Court of International Justice, the International Labour Organisation, the International Committee of Intellectual Cooperation, ${ }^{92}$ the Advisory Committee on Traffic in Opium and Other Dangerous Drugs, the International Institute of Agriculture, the Health Organisation, etc.

The interaction with other States led to further civilisational exchanges and brought India's culture to the front through her delegates. The delegates upheld the values like non-violence that the Indian civilisation stands for and spread them in international fora.

\footnotetext{
87 VERMA, supra note 18 , at 43 .

88 Id. at 78.

89 Gorman, supra note 82, at 126.

90 Legg, supra note 77 , at 234.

91 Id. at 244.

92 Jagdish Chandra Bose and Radha Krishnan were the members of the International Committee of Intellectual Cooperation. The aims of the committee were to develop "the interchange of knowledge and ideas among peoples and improving the conditions of intellectual work". RAM \& SHARMA, supra note 22, at 130.
} 


\section{Conclusion}

The present article aims at narrating an alternative history of the struggle of the Indians when colonial India became a member of the League of Nations. Its membership is lauded as a British boon. However, the narration behind the inclusion and the finance, and human resources India provided to the British gets receded to the background. There are many aspects that have changed in the post-colonial era. India is considered economically strong. However, history needs reiteration for self-introspection and for taking ideas of the past to create a better future. Colonial India's membership is a reminiscence of how the Empire shaped the international organisations for its own benefits. At the same time, it hides behind various struggles of Indians at the national, regional, and international levels. 